\title{
Decadal and Bi-Decadal Periodicities in Temperature of Southern Scandinavia: Manifestations of Natural Variability or Climatic Response to Solar Cycles?
}

\author{
Maxim Ogurtsov
}

Citation: Ogurtsov, M. Decadal and Bi-Decadal Periodicities in

Temperature of Southern Scandinavia:

Manifestations of Natural Variability

or Climatic Response to Solar

Cycles? Atmosphere 2021, 12, 676.

https://doi.org/10.3390/

atmos12060676

Academic Editor: Nicola Scafetta

Received: 7 May 2021

Accepted: 21 May 2021

Published: 25 May 2021

Publisher's Note: MDPI stays neutral with regard to jurisdictional claims in published maps and institutional affiliations.
Ioffe Physico-Technical Institute, 194021 St. Petersburg, Russia; maxim.ogurtsov@mail.ioffe.ru; Tel.: +7-921-416-2869

\begin{abstract}
Nine proxies of temperature over the last 225-300 years in Southern Fennoscandia $\left(55-63^{\circ} \mathrm{N}\right)$ were analyzed. Seven reconstructions of the mean growing season temperatures were obtained by dendroclimatological methods. Reconstructions of spring temperatures in Stockholm and winter temperatures in Tallinn were based on historical documentary sources. It was found that significant decadal (10-13 years) and bi-decadal (22-25 years) periodicities were present in many of these series during the entire time interval. Four proxy records correlated significantly with the quasi 22-year solar cycle of Hale. Three time series correlated significantly with the quasi 11-year solar cycle of Schwabe. This can be considered as evidence of a link between decadal and bi-decadal changes in solar activity and climate in Southern Fennoscandia. On the other hand, signs of correlation differed, as well as the time shift between the solar and temperature cycles. It is difficult to explain such an intricate relationship and, thus, the physical mechanism of solar-climatic linkages remains unclear. That is why assumptions about the purely occasional appearance of correlations cannot yet be rejected. Guidelines for further research are suggested.
\end{abstract}

Keywords: solar activity; climate; paleoclimatology

\section{Introduction}

The question of the reality of a relationship between solar activity and the Earth's climate and its possible physical mechanism is becoming increasingly important in solar-terrestrial research. Evidence of the solar influence on the climate of Northern Fennoscandia (NF) was obtained from a number of studies, based on the data of paleoclimatology [1-5]. On the other hand, some evidence against the Sun-climate link in NF was obtained as well [6,7]. Moreover, it was shown that the solar-climatic effects, if they really exist, have an apparent regional distribution [8-10]. That is why the study of possible solar-climatic associations in the area adjacent to NF is of great importance. Southern Fennoscandia (SF) is the region situated the closest to NF. This work is aimed at the analysis of solar-climate relations over the southern part of Scandinavia $\left(55-63^{\circ} \mathrm{N}, 10-35^{\circ} \mathrm{E}\right)$ during the 18th-20th centuries.

\section{Materials and Methods}

Paleoclimate reconstructions based on maximum latewood density (MXD) and historical documentary sources $(\mathrm{H})$ were used in this study (Table 1). Gridded summer temperatures over Europe, reconstructed by Briffa et al. [11], were presented in a gridpoint form on a $5^{\circ}$ latitude by $10^{\circ}$ longitude grid. 
Table 1. A list of proxy records used in this analysis.

\begin{tabular}{|c|c|c|c|c|}
\hline Reference & Region & Type of Proxy Data & Season & Period \\
\hline Briffa et al. [11] & $\left(55^{\circ} \mathrm{N}, 10^{\circ} \mathrm{E}\right)$ & MXD & April-September & $1750-1975$ \\
\hline Briffa et al. [11] & $\left(60^{\circ} \mathrm{N}, 10^{\circ} \mathrm{E}\right)$ & MXD & April-September & $1750-1975$ \\
\hline Briffa et al. [11] & $\left(60^{\circ} \mathrm{N}, 20^{\circ} \mathrm{E}\right)$ & MXD & April-September & $1750-1975$ \\
\hline Briffa et al. [11] & $\left(60^{\circ} \mathrm{N}, 30^{\circ} \mathrm{E}\right)$ & MXD & April-September & 1750-1975 \\
\hline Zhang et al. [12] & $\begin{array}{l}\text { West-Central Scandinavia } \\
\left(62.8-63.2^{\circ} \mathrm{N}, 13.2-14.9^{\circ} \mathrm{E}\right)\end{array}$ & MXD & April-September & $1700-2000$ \\
\hline Gunnarson et al. [13] & $\begin{array}{c}\text { Jämtland }\left(62.2-62.3^{\circ} \mathrm{N}\right. \\
\left.13.15-13.6^{\circ} \mathrm{E}\right)\end{array}$ & MXD & April-September & $1700-2000$ \\
\hline Helama et al. [14] & $\begin{array}{l}\text { Finnish Lakeland }\left(61.8-62.85^{\circ} \mathrm{N},\right. \\
\left.25.48-31.17^{\circ} \mathrm{E}\right)\end{array}$ & MXD & May-September & $1700-2000$ \\
\hline Leijonhufvud et al. [15] & Stockholm $\left(59.2^{\circ} \mathrm{N}, 18.03^{\circ} \mathrm{E}\right)$ & $\mathrm{H}$ & January-April & $1756-2000$ \\
\hline Tarand and Nordli [16] & Tallinn, Estonia, $\left(59.4^{\circ} \mathrm{N}, 24.75^{\circ} \mathrm{E}\right)$ & $\mathrm{H}$ & December-March & $1700-2000$ \\
\hline
\end{tabular}

A new improved version of the instrumental record of the sunspot number (SN) [17] was used as an indicator of the variations of the Sun's activity. In order to isolate the quasi 22-year Hale cycle from the original sunspot record, we firstly removed long-term changes in the $\mathrm{SN}$ and then constructed an alternate record $\mathrm{S}_{N}^{22}$-odd solar cycles were considered as positive and even ones as negative. Intensity of the galactic cosmic rays (GCR) can be a physical value, which follows the double solar cycle because drift and diffusion of charged particles is sensitive to changes of polarity of the Sun's magnetic field. During solar cycles with negative polarity (positive values of $S_{N}^{22}$ ) the cosmic ray flux displays a peaked form while during cycles with positive polarity (negative values of $S_{N}^{22}$ ) it has a flat-topped form (see [18]).

\section{Results}

Fourier spectra of the analyzed time series, calculated over the last 225-300 years, were used for detecting the periodicities in the temperature proxies (Figure 1, Table 2).

Table 2. Peaks of Fourier spectra of temperature reconstructions significant at more than 0.95 CI (1700-2000 AD).

\begin{tabular}{|c|c|c|c|c|}
\hline $\begin{array}{c}\text { Reconstructed } \\
\text { Variable (Reference) }\end{array}$ & Region & Period & Schwabe (9-14 Years) & Hale (18-25 Years) \\
\hline Briffa et al. [11] & $\left(55^{\circ} \mathrm{N}, 10^{\circ} \mathrm{E}\right)$ & 1750-1975 & & 24.7 \\
\hline Briffa et al. [11] & $\left(60^{\circ} \mathrm{N}, 10^{\circ} \mathrm{E}\right)$ & 1750-1975 & & 22.2 \\
\hline Briffa et al. [11] & $\left(60^{\circ} \mathrm{N}, 20^{\circ} \mathrm{E}\right)$ & $1750-1975$ & & 22.2 \\
\hline Briffa et al. [11] & $\left(60^{\circ} \mathrm{N}, 30^{\circ} \mathrm{E}\right)$ & 1750-1975 & & 22.2 \\
\hline Zhang et al. [12] & $\begin{array}{l}\text { West-Central Scandinavia } \\
\left(62.8-63.2^{\circ} \mathrm{N}, 13.2-14.9^{\circ} \mathrm{E}\right)\end{array}$ & $1700-2000$ & & \\
\hline Gunnarson et al. [13] & $\begin{array}{c}\text { Jämtland }\left(62.2-62.3^{\circ} \mathrm{N}\right. \\
\left.13.15-13.6^{\circ} \mathrm{E}\right)\end{array}$ & $1700-2000$ & & \\
\hline Helama et al. [14] & $\begin{array}{l}\text { Finnish Lakeland }\left(61.8-62.85^{\circ} \mathrm{N},\right. \\
\left.25.48-31.17^{\circ} \mathrm{E}\right)\end{array}$ & 1700-2000 & 13.0 & \\
\hline Leijonhufvud et al. [15] & Stockholm $\left(59.2^{\circ} \mathrm{N}, 18.03^{\circ} \mathrm{E}\right)$ & $1756-2000$ & $13.0,9.9$ & \\
\hline Tarand and Nordli [16] & Tallinn, Estonia, $\left(59.4^{\circ} \mathrm{N}, 24.75^{\circ} \mathrm{E}\right)$ & $1700-2000$ & $13.0,11.0,9.9$ & \\
\hline
\end{tabular}




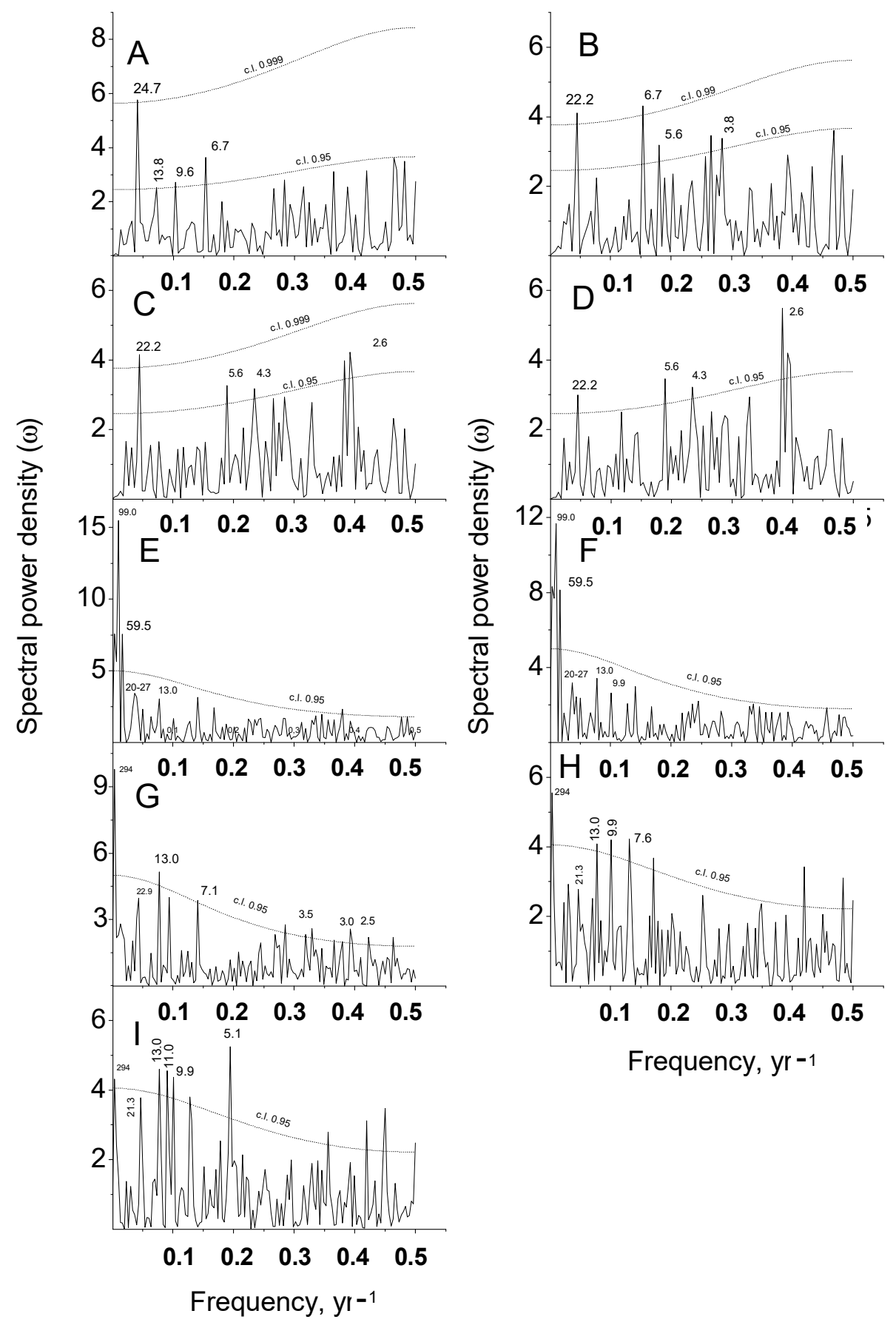

Figure 1. Fourier spectra of temperature reconstructions at: (A) $\left(55^{\circ} \mathrm{N}, 10^{\circ} \mathrm{E}\right)$ gridpoint [11]; (B) $\left(60^{\circ} \mathrm{N}, 10^{\circ} \mathrm{E}\right)$ gridpoint [11]; (C) $\left(60^{\circ} \mathrm{N}, 20^{\circ} \mathrm{E}\right)$ gridpoint [11]; (D) $\left(60^{\circ} \mathrm{N}, 30^{\circ} \mathrm{E}\right)$ gridpoint [11]; (E) Jämtland [13]; (F) West-Central Fennoscandia [12]; (G) Finnish Lakeland [14]; (H) Stockholm [15]; (I) Tallinn [16]. Dashed lines delineate confidence levels calculated for red and blue noises with AR(1) coefficient individual for each time series. Linear trends were subtracted prior to analyses.

Fourier analysis showed that:

(a) The significant $(p<0.05)$ quasi 22-24 year (bi-decadal) periodicity was found in four records of growing season temperature. In one of them-temperature at gridpoint $\left(55^{\circ} \mathrm{N}, 10^{\circ} \mathrm{E}\right)$, the significance of the bi-decadal variation exceeded 0.999 .

(b) The significant $(p<0.05)$ quasi 10-13 year (decadal) periodicity was present in three proxy records of the temperature in the growing season spring and winter.

(c) The significant $(p<0.05) 60$ year and 99 year periodicities were present in the summer temperatures of West-Central Scandinavia. These variations were likely manifes- 
tations of the century-scale (60-130 years) cyclicity which has been revealed in the Northern Fennoscandia temperature proxies and was attributed to solar activity changes [2,19].

Here, $p$ is a probability of null-hypothesis-the assumption that the peaks in the Fourier spectra were induced by red noises-random first-order autoregressive processes.

Weaker bi-decadal and decadal variations were present also in some other reconstructions, but they did not reach the $p<0.05$ level of significance. In order to further study the connection between the temperature data and solar forcing, the coefficients of linear (Pearson) correlation were calculated between solar cycles and the proxy records filtered using Hale (18.1-25.3 years) and Schwabe (8.6-14.1 years) scale bands. Wavelet filtration was performed by means of the real MHAT basis. The statistical significance $p$ of each of the calculated coefficients of correlation was assessed, using a statistical random-phase test, which included a number of 1000 Monte Carlo simulations of similarly smoothed time-series (see [2]) (Table 3).

Table 3. Correlation between the Southern Scandinavian temperature proxy records and solar activity data filtered using the Schwabe (8.6-14.1 years) and Hale (18.1-25.3 years) scale bands. The correlation coefficients with the significance exceeding 0.95, are shown with large font size. Phase shifts (forcing data leading the temperature data) in years are shown in the brackets, with the significance in italics, also in the brackets.

\begin{tabular}{cccc}
\hline Region & Period & Schwabe (9-14 Years) & Hale (18-25 Years) \\
\hline$\left(55^{\circ} \mathrm{N}, 10^{\circ} \mathrm{E}\right)$ & $1750-1975$ & $-0.04(1,<0.5)$ & $-0.26(2,0.75)$ \\
\hline$\left(60^{\circ} \mathrm{N}, 10^{\circ} \mathrm{E}\right)$ & $1750-1975$ & $0.15(1,0.83)$ & $\mathbf{- 0 . 6 1}(1,0.963)$ \\
\hline$\left(60^{\circ} \mathrm{N}, 20^{\circ} \mathrm{E}\right)$ & $1750-1975$ & $0.16(0,0.84)$ & $\mathbf{- 0 . 6 5}(1,0.982)$ \\
\hline$\left(60^{\circ} \mathrm{N}, 30^{\circ} \mathrm{E}\right)$ & $1750-1975$ & $0.16(0,0.82)$ & $\mathbf{- 0 . 6 4}(1,0.985)$ \\
\hline West-Central Scandinavia $\left(62.8-63.2^{\circ} \mathrm{N}\right.$, & $1700-2000$ & $\mathbf{0 . 3 1}(1,0.993)$ & $-0.20(2,0.78)$ \\
\hline $\begin{array}{c}\left.13.2-14.9^{\circ} \mathrm{E}\right) \\
\text { Jämtland }\left(62.2-62.3^{\circ} \mathrm{N}, 13.15-13.6^{\circ} \mathrm{E}\right)\end{array}$ & $1700-2000$ & $\mathbf{0 . 3 4}(1,0.988)$ & $-0.26(2,0.80)$ \\
\hline Finnish Lakeland $\left(61.8-62.85^{\circ} \mathrm{N}\right.$, & $1700-2000$ & $\mathbf{0 . 2 7}(1,0.985)$ & $-0.21(2,0.55)$ \\
\hline $\left.25.48-31.17^{\circ} \mathrm{E}\right)$ & $1756-2000$ & $0.08(0,<0.5)$ & $-0.47(6,0.86)$ \\
\hline Stockholm $\left(59.2^{\circ} \mathrm{N}, 18.03^{\circ} \mathrm{E}\right)$ & $1700-2000$ & $-0.09(0,<0.5)$ & $\mathbf{- 0 . 5 6 ( 6 , 0 . 9 8 3 )}$ \\
\hline Tallinn, Estonia, $\left(59.4^{\circ} \mathrm{N}, 24.75^{\circ} \mathrm{E}\right)$ & &
\end{tabular}

Correlation analysis showed that:

(a) Statistically significant $(p<0.05)$ negative correlation between climatic records and solar forcing data at a time scale relevant to the Hale (ca. 22 years) cycle was found for three reconstructions of the growing season temperature at latitude $60^{\circ} \mathrm{N}$ as well as for a proxy of winter temperature in Tallinn. Correlation reached maximum when the phase shift between the solar cycle and climatic reaction was 1 year for the summer temperature at $60^{\circ} \mathrm{N}$ and 6 years for the winter temperature in Tallinn.

(b) There was no significant correlation between strong 24.7 year periodicity in the growing season temperature at gridpoint $\left(55^{\circ} \mathrm{N}, 10^{\circ} \mathrm{E}\right)$ and the solar cycle of Hale.

(c) Statistically significant $(p<0.02)$ positive correlation between climatic records and solar forcing data at a time scale relevant to the Schwabe (ca. 11 years) cycle was found for three reconstructions of the growing season temperature in West-Central Scandinavia and Finnish Lakeland. Correlation was maximal when the phase shift was 1 year.

(d) There was no significant correlation between the 10-13 year variation of winter temperatures in Tallinn and the solar cycle of Schwabe. 


\section{Discussion and Conclusions}

Thus, the performed study showed that evidence of a solar-climatic connection exists, not only at Northern Fennoscandia but at Southern Fennoscandia as well. Moreover, while in NF the indications of solar-climatic communication have been obtained only for the warm season temperatures, in SF the correlation between the solar forcing and winter temperatures was observed as well (Tallinn). During a cold season, the effect is likely a bit more pronounced that is in line with the result of [20], obtained by means of the direct instrumental data. On the other hand, a ca. 25 year variation in the warm season temperatures at $\left(55^{\circ} \mathrm{N}, 10^{\circ} \mathrm{E}\right)$ and ca. 11 year variation in winter temperatures in Tallinn do not correlate with the corresponding solar cyclicities. It testifies that decadal and bi-decadal natural climatic oscillations not connected with solar activity were also present in Southern Scandinavia. The existence of inherent decadal and bi-decadal climatic instability can obscure solar-induced temperature variations and complicate the revealing of the solar-climatic linkage.

Correlations between the band-passed sunspot number and the temperature series have different signs at different frequency bands. The facts that (a) the climatic response to solar activity changes differed at different time scales and (b) the solar-climatic connection had an apparent spatial pattern are difficult to explain. The known possible mechanisms of solar-climatic linkage, including the direct effect of the total solar irradiance [21], the influence of the energetic particles of the galactic and solar cosmic rays on cloud cover $[22,23]$ and atmospheric circulation $[8,24]$, are unlikely to elucidate such complicated relationships. That means that solar-climatic connections, if they really exist, are likely to be rather complex and our knowledge about them still is limited. Moreover, the alternative explanation - that the revealed solar-type periodicities result from the natural instability of the climate system and the revealed correlations appear purely by chance-cannot be fully rejected. However, I have to emphasize that if the obtained correlations are not linked to the Sun's influence it means that climatic system can produce variations which are similar to solar periodicities over a long time. Figure 2 shows that 9-10 individual 22-year cycles in the temperature proxy [11] developed synchronously with the corresponding solar cycles through the entire time interval AD 1750-1975.

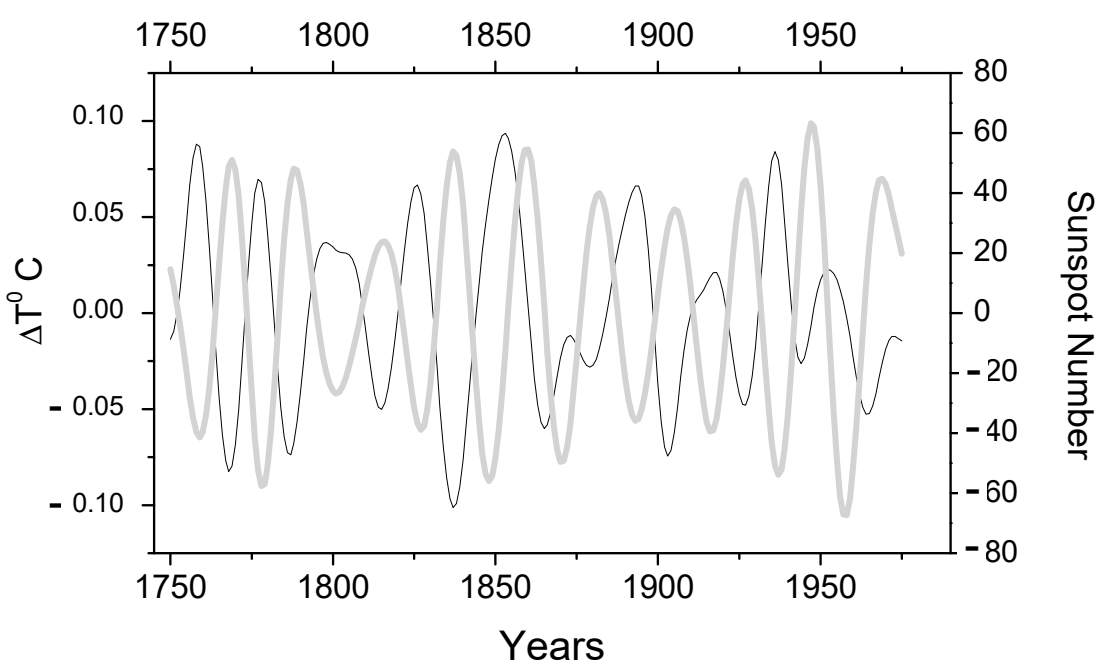

Figure 2. Time series wavelet filtered using Hale (18.1-25.3 years) scale band. Black line-temperature at gridpoint $\left(60^{\circ} \mathrm{N}, 30^{\circ} \mathrm{E}\right)$ [11], thick grey line-the record $\mathrm{S}_{N}^{22}$. Temperature is shifted by 1 year.

Such features in the climate of a rather wide region appear somewhat surprising.

Based on the obtained results, some directions for further research aimed at clarifying the question about the possible solar-climatic link can be proposed: 
(1) Obtaining and analyzing new independent reconstructions of temperature of different seasons in SF. It would allow the study of very local temperature variations over this region in more detail.

(2) Obtaining and analyzing the reconstructions of temperature over northeastern Europe area outside SF. It would allow the tracing of the regional distribution of the solar-type periodicities and the manifestations of the possible solar-climatic link in more detail.

(3) Expanding the time interval of the analysis by means of different proxies of the Sun's activity.

Funding: No additional funding.

Institutional Review Board Statement: Not applicable.

Informed Consent Statement: Not applicable.

Data Availability Statement: All climate data were taken from public data files provided by the World Data Service for Paleoclimatology (Boulder) and NOAA Paleoclimatology Program.

Conflicts of Interest: The author declares no conflict of interest.

\section{References}

1. Ogurtsov, M.G.; Kocharov, G.E.; Lindholm, M. Solar activity and regional climate. Radiocarbon 2001, 43, 439-447. [CrossRef]

2. Ogurtsov, M.; Lindholm, M.; Jalkanen, R.; Veretenenko, S.V. New evidence of solar variation in temperature proxies from Northern Fennoscandia. Adv. Space Res. 2013, 52, 1647-1654. [CrossRef]

3. Ogurtsov, M.; Veretenenko, S.V.; Helama, S.; Jalkanen, R.; Lindholm, M. Assessing the signals of the Hale solar cycle in temperature proxy records from Northern Fennoscandia. Adv. Space Res. 2020, 66, 2113-2121. [CrossRef]

4. Haltia-Hovi, E.; Saarinen, T.; Kukkonen, M.A. 2000-year record of solar forcing on varved lake sediment in eastern Finland. Quat. Sci. Rev. 2007, 26, 678-689. [CrossRef]

5. Helama, S.; Fauria, M.M.; Mielikäinen, K.; Timonen, M.; Eronen, M. Sub-Milankovitch solar forcing of past climates: Mid and late Holocene perspectives. GSA Bull. 2010, 122, 1981-1988. [CrossRef]

6. Ogurtsov, M.G.; Raspopov, O.M.; Helama, S.; Oinonen, M.; Lindholm, M.; Jungner, H.; Meriläinen, J. Climatic variability along a North-South transect of Finland over the last 500 years: Signature of solar influence or internal climate oscillations? Geogr. Ann. 2008, 90, 141-150. [CrossRef]

7. McCarroll, D.; Loader, N.J.; Jalkanen, R.; Gagen, M.H.; Grudd, H.; Gunnarson, B.E.; Kirchhefer, A.J.; Friedrich, M.; Linderholm, H.W.; Lindholm, M.; et al. A 1200-year multiproxy record of tree growth and summer temperature at the northern pine forest limit of Europe. Holocene 2013, 23, 471-484. [CrossRef]

8. Veretenenko, S.; Ogurtsov, M. Regional and temporal variability of solar activity and galactic cosmic ray effects on the lower atmosphere circulation. Adv. Space Res. 2012, 49, 770-783. [CrossRef]

9. Ogurtsov, M.; Veretenenko, S.; Lindholm, M.; Jalkanen, R. Possible solar-climate imprint in temperature proxies from the middle and high latitudes of North America. Adv. Space Res. 2016, 57, 1112-1117. [CrossRef]

10. Sfîcă, L.; Iordache, I.; Voiculescu, B. Solar signal on regional scale: A study of possible solar impact upon Romania's climate. J. Atmos. Solar Terr. Phys. 2018, 177, 257-265. [CrossRef]

11. Briffa, K.R.; Jones, P.D.; Schweingruber, F.H. Summer temperature patterns over Europe: A reconstruction from 1750 A.D. based on maximum latewood density indices of conifers. Quat. Res. 1988, 30, 36-52. [CrossRef]

12. Zhang, P.; Linderholm, H.W.; Gunnarson, B.E.; Björklund, J.; Chen, D. 1200 years of warm-season temperature variability in central Scandinavia inferred from tree-ring density. Clim. Past 2016, 12, 1297-1312. [CrossRef]

13. Gunnarson, B.E.; Linderholm, H.W.; Moberg, A. Improving a tree-ring reconstruction from west-central Scandinavia: 900 years of warm-season temperatures. Clim. Dyn. 2011, 36, 97-108. [CrossRef]

14. Helama, S.; Vartiainen, M.; Holopainen, J. A palaeotemperature record for the Finnish Lakeland based on microdensitometric variations in tree rings. Geochronometria 2014, 41, 265-277. [CrossRef]

15. Leijonhufvud, L.; Wilson, R.; Moberg, A.; Söderberg, J.; Retsö, D.; Söderlind, U. Five centuries of Stockholm winter/spring temperatures reconstructed from documentary evidence and instrumental observations. Clim. Change 2010. [CrossRef]

16. Tarand, A.; Nordli, P. The Tallinn temperature series reconstructed back half a millennium by use of proxy data. Clim. Change 2001, 48, 189-199. [CrossRef]

17. SILSO. World Data Center-Sunspot Number and Long-term Solar Observations, Royal Observatory of Belgium, on-line Sunspot Number catalogue. 2019. Available online: http:/ / www.sidc.be/SILSO (accessed on 21 May 2021).

18. Ferreira, S.E.S.; Potgeiter, M.S. Long-Term Cosmic-Ray Modulation in the Heliosphere. Astrophys. J. 2004, 603, 744-752. [CrossRef]

19. Ogurtsov, M.G.; Kocharov, G.E.; Lindholm, M.; Meriläinen, J.; Eronen, M.; Nagovitsyn, Y.A. Evidence of solar variation in tree-ring-based climate reconstructions. Sol. Phys. 2002, 205, 403-417. [CrossRef]

20. Veretenenko, S.; Pudovkin, M. Latitudinal dependence of helio/geophysical effects on the solar radiation input to the lower atmosphere. J. Atmos. Solar Terr. Phys. 2000, 62, 567-572. [CrossRef] 
21. Mendoza, B. Total solar irradiance and climate. Adv. Space Res. 2005, 35, 882-890. [CrossRef]

22. Marsh, N.; Svensmark, H. Low cloud properties influenced by cosmic rays. Phys. Rev. Lett. 2000, 85, 5004-5007. [CrossRef] [PubMed]

23. Palle, E.; Buttler, C.J.; O’Brien, K. The possible connection between ionization in the atmosphere by cosmic rays and low level clouds. J. Atmos. Solar Terr. Phys. 2004, 66, 1779-1790. [CrossRef]

24. Veretenenko, S.; Ogurtsov, M. Stratospheric polar vortex as a possible reason for temporal variations of solar activity and galactic cosmic ray effects on the lower atmosphere circulation. Adv. Space Res. 2014, 54, 2467-2477. [CrossRef] 